\title{
PENGARUH MODEL DISCOVERY LEARNING TERHADAP KEMAMPUAN BERPIKIR KREATIF MATEMATIS SISWA
}

\author{
EMY SOHILAIT \\ Pendidikan Matematika, STKIP Gotong Royong Masohi, Kabupaten Maluku Tengah, Maluku \\ sohilaitemy@gmail.com
}

First Received: 19-01-2021; Accepted: 23-04-2021

\begin{abstract}
Abstrak
Penelitian ini dilatarbelakangi oleh rendahnya kemampuan berpikir kreatif matematis siswa pada materi eksponen dan logaritma. Berdasarkan kondisi yang telah dikemukakan, maka diperlukan suatu pembelajaran yang dapat mengoptimalkan kemampuan berpikir kreatif matematis. Salah satu pembelajaran yang diperkirakan dapat meningkatkan kemampuan berpikir kreatif siswa adalah model discovery learning. Tujuan penelitian ini adalah mengetahui pengaruh model discovery learning terhadap kemampuan berpikir kreatif matematis siswa kelas $\mathrm{X}$ SMK Negeri 1 Masohi. Jenis penelitian ini merupakan penelitian eksperimen yang terdiri dari variabel bebas yaitu model discovery learning dan variabel terikat yaitu kemampuan berpikir kreatif matematis. Sampel dalam penelitian ini diambil dengan menggunakan teknik purposive sampling dengan kelas X1 sebagai kelas eksperimen berjumlah 18 orang dan siswa kelas X2 berjumlah 18 orang sebagai kelas kontrol. Instrumen penelitian yang digunakan adalah tes kemampuan berpikir kreatif matematis siswa bejumlah 6 soal. Berdasarkan hasil penelitian dan pembahasan dapat disimpulkan bahwa: terdapat pengaruh pengaruh model discovery learning terhadap kemampuan berpikir kreatif matematis siswa kelas X SMK Negeri 1 Masohi. Hasil uji-t menunjukan bahwa $t$ hitung $=2,27>\mathrm{t}$ tabel $=2,03$ Dari hasil perhitungan didapat $\mathrm{t}$ hitung $=2,27$ ternyata tidak masuk dalam daerah penerimaan Ho yaitu antara - 2,03 sampai dengan 2,03; maka H0 ditolak dan H1 diterima. Sehingga dapat disimpulkan bahwa terdapat pengaruh dari penggunaan model discovery learning terhadap kemampuan berpikir kreatif matematis siswa kelas $\mathrm{X}$ SMK Negeri 1 Masohi.
\end{abstract}

Kata kunci: Kemampuan berpikir kreatif; Model discovery learning

\section{THE INFLUENCE OF DISCOVERY LEARNING MODELS ON STUDENTS' MATHEMATICAL CREATIVE THINKING ABILITIES}

\begin{abstract}
This research is motivated by the low ability of students to think creatively in mathematics on exponential and logarithmic material. Based on the conditions that have been stated, it is necessary to have a study that can optimize mathematical creative thinking skills. One of the lessons that are thought to improve students' creative thinking skills is discovery learning models. The purpose of this study was
\end{abstract}


to determine the effect of the discovery learning model on the mathematical creative thinking skills of class X students of SMK Negeri 1 Masohi. This type of research is an experimental study consisting of independent variables, namely discovery learning models and the dependent variable, namely the ability to think mathematically creatively. The sample in this study was taken using purposive sampling technique with class $\mathrm{X} 1$ as the experimental class amounting to 18 people and class X2 students totaling 18 people as the control class. The research instrument used was a test of students' mathematical creative thinking skills in a total of 6 questions. Based on the results of the research and discussion, it can be concluded that: there is an influence of the discovery learning model on the mathematical creative thinking ability of class X students of SMK Negeri 1 Masohi. The result of $\mathrm{t}$-test shows that $\mathrm{t}$ count $=2.27>\mathrm{t}$ table $=2.03$. From the calculation, it is found that $\mathrm{t}$ count $=2.27$ turns out not to be included in H0's reception area, between -2.03 to 2.03; then $\mathrm{H} 0$ is rejected and $\mathrm{H} 1$ is accepted. So it can be concluded that there is an influence from the use of discovery learning models on the mathematical creative thinking ability of class X students of SMK Negeri 1 Masohi.

Keywords: Creative thinking skills; Discovery learning model

\section{PENDAHULUAN}

Pembelajaran yang diterapkan oleh para guru saat ini adalah menggunakan Kurikulum 2013. Kurikulum 2013 merupakan kurikulum dengan proses pembelajaran yang terdiri dari pengalaman belajar: mengamati, menanya, mengumpulkan informasi, mengasosiasi, dan mengkomunikasikan (Muhammad, 2016). Kurikulum 2013 masih sangat baru dalam dunia pendidikan. Banyak hal yang terpengaruh oleh kurikulum, metode mengajar, maupun strategi mengajar. Salah satu yang dipengaruhi adalah kemampuan berpikir kreatif.

Berdasarkan hasil observasi dengan guru matematika pada bulan Oktober 2020 ditemukan bahwa kemampuan berpikir kreatif matematis siswa kelas X Sekolah Menengah Kejuruan (SMK) Negeri 1 Masohi pada materi Eksponen dan Logaritma ditemukan bahwa siswa kurang terampil dalam memahami suatu masalah, kurang terampil memecahkan suatu masalah dan menemukan alternatif-alternatif pemecahan yang bervariasi atau dengan kalimat lain siswa cenderung memberikan jawaban yang sama, dan terkadang hanya mengikuti langkah yang ada di buku paket atau cara yang telah ada. Belum tampak adanya penemuan ide baru maupun mengaitkan materi dengan dunia nyata yang dilakukan oleh siswa, dikatakan ada namun jarang sekali. Karena kurangnya pelatihan tentang berfikir kreatif matematis terutama dalam pemecahan masalah matematika, banyak siswa yang kurang berkenan mengenai mata pelajaran matematika.

Faktor yang menyebabkan kemampuan berpikir kreatif matematis siswa rendah diantaranya pembelajaran yang disajikan guru masih konvensional dan kurang menarik, guru jarang menggunakan media pembelajaran yang sesuai sehingga kemampuan berpikir kreatif 
siswa masih rendah, guru kurang mampu mendayagunakan media yang tersedia di sekolah, guru mengalami kesulitan dalam menemukan model dan metode yang tepat untuk menyajikan pembelajaran yang aktif dan kreatif. Selain itu guru kurang mengarahkan dan memotivasi siswa untuk mengaitkan permasalahan yang dihadapi dengan kehidupan sehari-hari dan memunculkan ide-ide kreatif melalui pembuatan suatu karya.

Berpikir kreatif matematis memuat aspek ketrampilan kognitif, afektif, dan metakognitif (Werdiningsih, 2019). Berpikir kreatif matematis juga memuat empat komponen yaitu: (1) kelancaran (elaboration) adalah jika siswa mampu menyelesaikan masalah matematika dengan beberapa alternatif jawaban (beragam) dan benar. (2) fleksibel (flexibility) adalah jika siswa mampu menyelesaikan masalah matematika dengan cara yang berbeda. (3) keaslian (originality) menciptakan sesuatu yang belum pernah ada sebelumnya dengan pemikiran sendiri. (4) elaborasi (elaboration) mampu menyampaikan pesan atau informasi dengan baik. Berbicara tentang berpikir kreatif matematis tentu tidak lepas dari kreativitas. Menurut Munandar (Werdiningsih, 2019) kreativitas adalah ungkapan (ekspresi) dari keunikan individu dalam interaksi lingkunganya. Pemikiran yang kreatif adalah pemikiran yang berusaha melahirkan sesuatu yang baru dan disandarkan kepada prinsip-prinsip kemungkinan. Kita disebut kreatif ketika kita memutuskan untuk membuka diri terhadap sesuatu yang belum kita ketahui.

Untuk mengatasi rendahnya kemampuan berfikir kreatif dan untuk membentuk pribadi yang kreatif maka proses pembelajaran yang dilaksanakan harus juga menumbuhkembangkan kemampuan berpikir kreatif sehingga mampu mengembangkan kemampuan kreativitasnya. Oleh karena itu, pembelajaran harus memberikan nuansa yang nyaman dan memberi motivasi dalam belajar agar proses belajar dapat tumbuh dan berkembang secara optimal. Oleh karena itu, peneliti menggunakan model discovery learning.

Model discovery learning merupakan model pembelajaran yang digunakan untuk membangun konsep dibawah pengawasan guru (Nahdi \& Apriadi, 2015). Terdapat langkahlangkah pada model ini yaitu: stimulation, problem statement, data collection, data processing, verification and generalization. Tumurun et al. (2016) menyatakan bahwa menggunakan model discovery learning ini siswa akan mampu untuk mengembangkan keterampilan berpikir kreatifnya. Hal ini dikarenakan model discovery learning memiliki tahapan tahapan yang mampu untuk melatih siswa berpikir kreatif. Tahapan-tahapan tersebut diantaranya orientasi atau menemukan masalah, dan merumuskan masalah. Pada tahapan ini siswa dilatih dua indikator berpikir kreatif yaitu lancar dan luwes. Kemudian dilakukan tahapan merencanakan 
pemecahan masalah melalui percobaan atau cara lain pembelajaran. Pada tahapan ini siswa dilatih memiliki salah satu indikator keterampilan berpikir kreatif yaitu berpikir orisinil. Setelah merencanakan pemecahan masalah siswa kemudian melakukan percobaan. Pada tahapan melakukan percobaan siswa dilatih untuk memiliki indikator berpikir kreatif yaitu berpikir elaboratif. Selanjutnya siswa melakukan analisis data yang terah mereka temukan. Pada tahapan ini siswa dilatih untuk berpikir lancar, luwes, dan elaboratif. Setelah melakukan analisis data siswa diminta untuk menyimpulkan hasil dari percobaan yang telah mereka buat.

Dengan demikian model discovery learning mempunyai tujuan utama untuk mengembangkan ketrampilan intelektual, berpikir kreatif, dan mampu memecahkan masalah secara ilmiah. Mohammad Takdir Ilahi dalam bukunya berjudul "Pembelajaran Discovery Strategy \& Mental Vocational Skill" menyatakan bahwa salah satu bukti konkret implikasi pembelajaran discovery dapat meningkatkan vocational skill. Salah satu implikasi tersebut adalah kemampuan siswa untuk berpikir kreatif. Secara tidak langsung Takdir menyatakan bahwa model discovery dapat meningkatkan kemampuan berpikir kreatif.

Berdasarkan berbagai hal tersebut, maka disusun penelitian dengan tujuan untuk mengetahui pengaruh model discovery learning terhadap kemampuan berpikir kreatif matematis siswa kelas X SMK Negeri 1 Masohi.

\section{METODE PENELITIAN}

Metode yang digunakan pada penelitian ini adalah penelitian eksperimen semu. Desain penelitian yang digunakan adalah posttest- only control design.

Tabel 1. Desain Penelitian

\begin{tabular}{ccc}
\hline Kelompok & Perlakuan & Posttest \\
\hline Eksperimen & $X_{E}$ & $Y_{E}$ \\
Kontrol & $X_{K}$ & $Y_{K}$ \\
\hline
\end{tabular}

Keterangan:

$X_{E}$ : Perlakuan yang diberikan pada kelas eksperimen

$X_{E}$ : Perlakuan yang diberikan pada kelas kontrol

$Y_{E}$ : Skor hasil dengan tes yang sama pada kelas eksperimen

$Y_{E}$ : Skor hasil dengan tes yang sama pada kelas kontrol

Penelitian dilaksanakan pada Sekolah Menengah Kejuruan (SMK) Negeri 1 Masohi tahun ajaran 2020/2021. Populasi penelitian ini seluruh siswa kelas X Sekolah Menengah Kejuruan (SMK) Masohi berjumlah 45 siswa yang terbagi dalam 2 kelas. Teknik sampling yang digunakan teknik purposive sampling dengan kelas X1 sebagai kelas eksperimen 
berjumlah 18 orang dan siswa kelas X2 berjumlah 18 orang sebagai kelas kontrol. Instrumen kemampuan berpikir kreatif matematis yang digunakan adalah soal essay kemampuan berpikir kreatif matematis. Teknik pengolahan data yang digunakan dalam penelitian ini menggunakan uji validitas ahli, yaitu dosen pendidikan Matematika dan dosen pendidikan Bahasa dan Sastra Indonesia. Dengan tujuan untuk mengetahui kualitas dari instrumen yang akan digunakan. Data yang diperoleh dari tes kemampuan berpikir kreatif matematis dianalisis dengan uji independent t-test. Uji independent t-test dilakukan setelah memenuhi uji prasyarat, yaitu uji normalitas dan uji homogenitas. Uji normalitas digunakan untuk mengetahui distribusi data. Distribusi data digunakan untuk mengetahui analisis yang akan digunakan. Analisis menggunakan uji independent $t$-test apabila data berdistribusi normal dengan uji Lilliefors.

\section{HASIL DAN PEMBAHASAN}

Pengujian normalitas dengan uji Lilliefors dilakukan untuk mengetahui normal tidaknya suatu distribusi data. Hal ini penting diketahui berkaitan dengan ketepatan pemilihan uji statistik yang akan dipergunakan.

Tabel 2. Uji Normalitas

\begin{tabular}{cccc}
\hline Kelas & $\boldsymbol{L}_{\text {hitung }}$ & $\boldsymbol{L}_{\text {tabel }}$ & Keterangan \\
\hline Eksperimen & 0,123 & 0,200 & Berdistribusi Normal \\
\hline Kontrol & 0,1111 & 0,200 & Berdistribusi Normal \\
\hline
\end{tabular}

Pengujian homogenitas dengan uji Bartlett dilakukan untuk mengetahui kedua kelas homogen atau tidak homogen.

Tabel 3. Uji Homogenitas

\begin{tabular}{cccccc}
\hline Kelas & Jumlah & Varians & $\boldsymbol{X}_{\text {hitung }}$ & $\boldsymbol{X}_{\text {tabel }}$ & Kesimpulan \\
\hline Eksperimen & 18 & 15,0 & 0,184 & 3,841 & Homogen \\
\hline Kontrol & 18 & & & & \\
\hline
\end{tabular}

Hipotesis yang digunakan untuk kemampuan berpikir kreatif matematis siswa kelas $\mathrm{X}$ SMK Masohi sebagai berikut:

$H_{0}$ : Kemampuan berfikir kreatif siswa yang belajar menggunakan model discovery learning tidak lebih tinggi dari kemampuan berfikir kreatif dengan model pembelajaran konvensional.

$H_{1}$ : Kemampuan berfikir kreatif siswa yang belajar menggunakan model discovery learning lebih tinggi dari kemampuan berfikir kreatif dengan model pembelajaran konvensional.

Berdasarkan hasil perhitungan uji $t$ diperoleh $t_{\text {hitung }}=2,27>t_{\text {tabel }}=2,03$, maka dapat 
dikatakan bahwa terdapat pengaruh yang signifikan terhadap kemampuan berpikir kreatif matematis siswa pada materi Eksponen dan Logaritma yang menggunakan model discovery learning. Hasil perhitungan statistik deskriptif di bawah ini dapat menunjukan bahwa model discovery learning lebih tinggi dari model pembelajaran konvensional.

Tabel 3. Perhitungan Statistik Deskriptif

\begin{tabular}{lrr}
\hline Statistik & Kelas Eksperimen & Kelas Kontrol \\
\hline Ukuran Sampel & 18 & 18 \\
Nilai Max & 93 & 87 \\
Nilai Min & 47 & 27 \\
Rentan skor & 46 & 60 \\
Mean & 71,44 & 60,00 \\
Standar deviasi & 14,32 & 15,84 \\
Varians & 205,06 & 251,90 \\
Modus & 73 & 60 \\
Median & 73 & 60 \\
Jumlah & 1286 & 1080 \\
\hline
\end{tabular}

Berdasarkan perhitungan di atas pada data penelitian diperoleh rata-rata penelitian kelas eksperimen adalah 80,95 dengan varians 205,06. Sedangkan rata-rata kelas kontrol adalah 60,00 dengan varians 251,90. Maka diperoleh $t_{\text {hitung }}=2.27$ nilai statistik t pada taraf signifikan $\alpha=0,05=t_{\text {tabel }}=2,03$ maka tolak $H_{0}$, dan dapat dikatakan bahwa terdapat pengaruh yang signifikan kemampuan berpikir kreatif matematis siswa. Karena $H_{0}$ ditolak ditunjukkan keunggulan rata-rata kemampuan berpikir kreatif matematis siswa kelas eksperimen terhadap kelas kontrol adanya perbedaan kemampuan berpikir kreatif matematis siswa.

Berdasarkan kenyataan di lapangan saat melakukan penelitian di kelas dengan menerapkan model discovery learning, terdapat kelemahan yang nampak selama proses pembelajaran berlangsung yaitu memerlukan waktu yang lebih lama. Hal tersebut dikarenakan adanya langkah-langkah pembelajaran yang lebih banyak dalam penerapan model. Namun dapat diatasi dengan cara lebih disiplin dalam penggunaan waktu pembelajaran agar tujuan pembelajaran dapat terpenuhi dengan waktu yang efisien.

Model discovery learning dirancang untuk membantu siswa mengembangkan kreatif dalam menyelesaikan masalah. Dengan demikian dapat disimpulkan bahwa model pembelajaran ini memiliki pengaruh positif di SMK Negeri 1 Masohi dari pada siswa yang menggunakan model pembelajaran konvensional. 


\section{SIMPULAN}

Berdasarkan hasil penelitian ini dapat disimpulkan bahwa model discovery learning berpengaruh signifikan terhadap kemampuan berpikir kreatif matematis siswa, artinya bahwa nilai skor hasi tes kemampuan berpikir kreatif matematis siswa pada kelas eksperimen dengan menggunakan model discovery learning lebih tinggi dibandingan pada kelas kontrol dengan menggunakan model pembelajaran konvensional. Dengan demikian model discovery learning berpengaruh secara signifikan terhadap kemampuan berpikir kreatif matematis siswa.

\section{UCAPAN TERIMA KASIH}

Terbitnya tulisan ini tidak terlepas dari bantuan berbagai pihak, untuk itu penulis ucapkan terima kasih kepada Prodi Pendidikan Matematika STKIP Pamane Talino Kalimantan Barat dan pengelola jurnal Riemann yang telah memberikan saran dan revisi dalam penulisan artikel ini.

\section{DAFTAR PUSTAKA}

Muhammad, A. (2016). Penelitian Pendidikan Prosedur dan Strategi. Bandung Angkasa.

Nahdi, D. S., \& Apriadi, F. (2015). PENGARUH MODEL DISCOVERY LEARNING TERHADAP KEMAMPUAN BERPIKIR KREATIF SISWA PADA MATA PELAJARAN ILMU PENGETAHUAN ALAM. Jurnal Cakrawala Pendas, 1(2), 66-71.

Tumurun, S. W., Gusrayani, D., \& Jayadinata, A. K. (2016). PENGARUH MODEL PEMBELAJARAN DISCOVERY LEARNING TERHADAP KETERAMPILAN BERPIKIR KREATIF SISWA PADA MATERI SIFAT-SIFAT CAHAYA. Jurnal Pena Ilmiah. https://doi.org/10.23819/pi.v1i1.2936

Werdiningsih, C. E. (2019). Prosiding DPNPM Unindra 2019. Pengaruh Model Pembelajaran Discovery Learning Terhadap Kemampuan Berpikir Kreatif Pada Siswa Kelas VII SMP Bekasi, 399-404. 